\title{
The Role of Customer Experience in Brand Royalty and Emotional Intention of Cars in Chennai
}

\begin{abstract}
The intend of research articles is to recognize the outcome of brand loyalty on purchase of Cars. Questionnaires were circulated to gather the responses from the various consumers. Brand knowledge and brand reliability have strong positive relationship with purchase of car. The study reveals that the buyer has the awareness of the particular product and the qualities that identifies the consumer's level. Brand loyalty buildings a strong customer base and helps to frame towards succeed in the market. Percentage statistical tool was used to analyze the data and draw the conclusions.
\end{abstract}

Keywords: Brand loyalty, Customer experience, Emotional intention.

\section{INTRODUCTION}

$\mathrm{B}_{\text {rand reliability is a blueprint of buyer behavior through }}$ which customers is likely to get dedicated to a precise brand. The increased awareness had made lot of changes in the consumer towards purchase of cars. The price, models, color, brand comfort were also influence the purchase decision of consumers. A consumer will frequently purchase the same product because they identify it a superior product among the choices available in the market. Businesses plan different innovative marketing strategies to create brand loyalty to attract the consumers. Devoted customers search several stores for their favorite brands to satisfy themselves.

The consumers can become the reliable to the brand due to its de, feel easy, design comfort and latest innovative in the brand by using that particular brand and they also have adequate knowledge of the brand and feel confident while purchase. Customers buying judgment can be either aware or unconscious; however, it is based upon trust that the brand fulfils the customers. Brand loyalty is based upon exciting relationship which is created between the brand and the consumer. It is supposed by the customer that the brand will accomplish some type of touching feel needs in an exclusive way and which evokes emotions while purchasing and using the brand.

Customer experience be measured as a psychological concept; the study shows the consumers experience and emotional intention to purchase of car. Emotions play a vast role in our personal lives, and clearly reveals customer

Revised Manuscript Received on December 05, 2019.

* Correspondence Author

N. Jeeva*, Research scholar, Department of Commerce, University of Madras, Chennai, India. behavior, attitude and ultimately business. Emotions are key ingredients to motivation of consumers for purchase of car. Finally it clears that customers experience like commitment, trust, value, satisfaction, brand loyalty are the vital role towards purchase of cars. For example a customer emotionally feels to have car with good music system to enjoy while driving with their family members.

\section{OBJECTIVES}

1. To classify the factors influencing of customer's Emotional experience and product loyalty.

2. To examine the consumers brand reliability towards cars within Chennai City.

\section{LIMITATIONS OF THE STUDY}

Because of time constraint only 50 respondents was selected. The study is conducted in Chennai only. The findings along with analysis made in the study depend fully on the information given by the respondents. The data is collected through questionnaire method. The accuracy of findings was limited by the statistical tools used in research.

\section{REVIEW OF LITERATURE}

The study is expressive in nature and only secondary data has been used in it. The secondary data consists of the books, news papers, company report and various research journals. This section attempts to evaluate the prose of the major concepts and theories of Customers experience in brand loyalty of cars. An appraisal of these studies is helps to develop appropriate approaches towards the study.

Dhruv Mathur, Avdesh Bhardawaj, Aditi Pandey, Ashish Oberoi, (2018) reveals the consumers buying behavior of car. Data's were collected to people using different tools like e-mail, WhatsApp, Face book, etc. It shows that latest technology and television influence the purchase of cars. Further is reveals that the research have studied factors like family needs, fuel efficiency, pricing, safety and social Status as important in automobile buying behavior of the consumer. It concluded that the buying behavior of cars is influenced by type and brand image of the cars and manufacturers. The engine type, efficiency and good advertising with detailed features are the factors that influence the potential car customers.

Rajesh Ittamalla (2018) identifies the determinants of

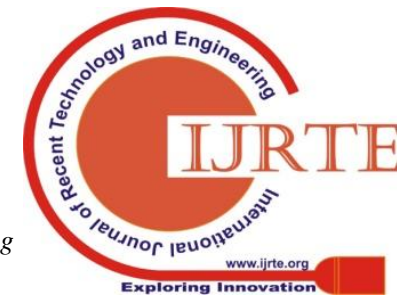


online consumer experience.

The study follows the systematic methodology to review the literature. The study concludes the concept of customer experience in online context and identified antecedent factors to the online customer experience. The study reveals antecedent factors to the online customer experience. Further it shows that Customer experience is a combination of both cognitive and emotional aspects.

Manas Ranjan Rath and S Vasantha (2018) reveal a model structure for Emotional Intelligence (EI) functions in organization. EI in an organization has been developed to organize to career based EI competency requirement of individuals for higher organizational effectiveness. The Findings reinforces the high importance of EI in organization. Its significance shows that EI enhance ability of employee to improve interpersonal relationships for higher organizational effectiveness. Further helps for career advancement \& elevation in senior \& middle level managerial positions. EI should be a far more important criterion than managerial skills \& intellect.

Wan Nadia, Mohd Nadzri, \& Rosidah Musa (2014) focus to Explore Brand Experience and excavate consumer's experience. The study clearly shows the emotion of consumers towards selecting their brand of car. It facilitates the possible in creating improvement and the expansion of enhanced customer relationships. The results help national car producers to go through global market by adapting latest consumer brand experience.

Chao and I-Han, Chen (2014) explore the level of experiential marketing influences user plan on purchase. The study reveals that there is an important disparity in experiential marketing across different demographic variables, including age, educational level and average monthly income. From the study finds that, attributes of emotional, thought, action, associative, and sensory experiences of consumers are helpful in increasing customer purchase intention.

Vishwas Maheshwari1, George \& Siril- (2014) the research focused main two factors are brand knowledge and brand assurance to inspect its relationships. The study investigates a connection between brand experience and brand loyalty. It suggests that consumers have emotional feeling towards brand loyalty.

\section{RESEARCH DESIGN}

A research design can be defined as the blue print and stage of action in the course of research. Research design is the compilation and examination of data. Descriptive research design was adopted for the study.

\section{A. Statistical tools used for Analysis}

Statistical tools constitute a vital part of research analysis. Hence, an analysis of data complied should be subjected to relevant analysis. The percentage analysis is used for this study.

Percentage analysis: The percentage of a particular with categories is calculated in order to get a fair idea regarding the sample. These are used in making comparisons between two or more series of data.

Percentage of Respondents $=\frac{\text { No. of respondents x } 100}{\text { Total no. of }}$ respondents

\section{INVESTIGATION AND INTERPRETATIONS}

The intend of the study is to organize, represent, describe, and recap the collected data so that they can be better comprehended and interpreted to give answers to the questions that triggered the research.

Table - 1: Socio-Economic Profile of the Respondents

\begin{tabular}{|c|c|}
\hline Demographic Profile & Frequency \\
\hline \multicolumn{2}{|l|}{ Sex } \\
\hline Male & 31 \\
\hline Female & 19 \\
\hline \multicolumn{2}{|l|}{ Age } \\
\hline $25-35$ Years & 05 \\
\hline $35-45$ Years & 15 \\
\hline $45-55$ Years & 30 \\
\hline Above 55 Years & 01 \\
\hline \multicolumn{2}{|l|}{ Qualification } \\
\hline School & 07 \\
\hline Diploma & 12 \\
\hline UG & 20 \\
\hline PG & 09 \\
\hline Professional & 02 \\
\hline \multicolumn{2}{|l|}{ Marital Status } \\
\hline Single & 02 \\
\hline Married & 48 \\
\hline \multicolumn{2}{|l|}{ Family Type } \\
\hline Nuclear & 20 \\
\hline Joint & 30 \\
\hline \multicolumn{2}{|l|}{ Family Size } \\
\hline 2 & 01 \\
\hline 3 & 16 \\
\hline 4 & 15 \\
\hline More than 4 & 18 \\
\hline \multicolumn{2}{|l|}{ Occupation } \\
\hline Business & 19 \\
\hline Professional & 03 \\
\hline Private Employee & 15 \\
\hline Government Employee & 13 \\
\hline \multicolumn{2}{|l|}{ Monthly Income } \\
\hline Below 25K & 02 \\
\hline $25 \mathrm{~K}-50 \mathrm{~K}$ & 25 \\
\hline $50 \mathrm{~K}-1 \mathrm{Lakh}$ & 23 \\
\hline
\end{tabular}


The above results indicate that the table specifies the gender of the respondents $31 \%$ is males and $19 \%$ are female. In age the maximum group of the respondents $30 \%$ are from $45 \mathrm{yrs}$ to $55 \mathrm{yrs}$ and $5 \%$ is the minimum from the age group of $25 y$ rs to $35 y r s . I n$ educational the maximum respondents $20 \%$ are under UG and the minimum is professional consumer towards preferred brand of cars. The table reveals the fact that marital status of the respondents indicates $48 \%$ are married and $2 \%$ are unmarried.

The above table found that family type $30 \%$ is from joint and $20 \%$ are nuclear family. The size of the indicates $18 \%$ are more than four numbers and that $1 \%$ are from 2 numbers. In occupation reveals that $19 \%$ are from business and $3 \%$ are from professional which influence the purchase intention of cars. The above specify the income also of respondents are $25 \%$ from 25000 to 50000 and $23 \%$ are from 50000 to 100000 .

"The brand loyalty of the customer base is often the core of brand equity. If customers are indifferent to the

\section{CONCLUSION}

The principle of this article was to generate a deeper thought about the power of brand royalty and emotional experience of customers towards cars. From the revise it is obvious that well familiar branded cars are very famous and consumers belief the brand name. Brand loyalty represents an hopeful move towards a brand which resulting in regular purchase of the brand .Further it focuses on the hidden confidential experiences stored in the consumer's memory, sparkly the emotional responses to the brand stimuli. Further it clears form the study consumers are attached brand loyalty towards their purchase of cars. Hence it concluded that customers with emotional relation with the brand, brings more confidence.

\section{REFERENCES}

1. Ashish Oberoi Dhruv Mathur, Bhardawaj,Aditi Pandey, ,( 2018) Consumer Buying Behaviour of Cars in India - A Survey School of Management, The NorthCap University Gurugram, Haryana-122017 India

2. Rajesh Ittamalla (2018), Customer Experience Determinants: Review in Online Purchase Context. 10.5958/2249-7315.2018.00030.8.

3. Manas Ranjan Rath, S Vasantha, (2018)- Developing a Framework for Emotional Intelligence Functions in a Small Organisation DOI Number: 10.5958/0976-5506.2018.00029.3

4. Wan Nadia, Mohd, \& Rosidah Musa , In their research - Focus Group Method an Aid to Explore Brand Experience and Contextual Factors (2014)

5. Chao-Chien and I-Han, Chen. ( 2014) _ “ A Study of the Effect of Experiential Marketing on Customer Purchase Intention: Case Study of the Taipei"

6. Vishwas Maheshwari1, George \& Siril Jacobsen, ( 2014 )- “ Determinants of Brand Loyalty: (2014)

\section{AUTHORS PROFILE}

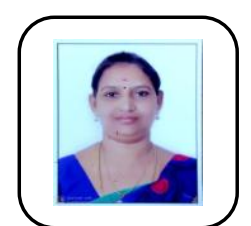

N. Jeeva, M.com, M. Phil, M.Ed., is an Assistant Professor in Department of Commerce, Anna Adarsh College for Women. Author has a decade of teaching experience. The author's specialized area is finance, Taxation and Marketing. The author has published and presented many research papers in National International in UGC list journal and Conference 